\title{
Den unge Grundtvig og Norge
}

\author{
AfGustav Albeck
}

Grundtvigs forhold til Norge var af en ganske speciel natur. Han var 67 år gammel, altså hvad man i hans dage kaldte en olding, før han kom til at betræde Norges klippegrund. Men fra sin tidligste ungdom - $\mathrm{i}$ den nordiske romantiks gyldne dage - havde han ad boglig vej levet sig ind i Norge - dets natur og historie. Han var 31 år gammel, da svenskerne i 1814 tvang den mere end 400 år gamle dansk-norske samhørighed til ophør. Betegnelsen Tvillingriget var for ham ikke nogen tom frase, men en historisk og åndelig realitet. Hans tidlig vakte fædrelandskærlighed gjaldt dobbeltmonarkiet. For ham som for den unge Oehlenschläger var fædrelandet ikke blot de grønne danske øer, men også de mørke norske fjelde. Ligesom Oehlenschläger søgte han i sin ungdom fædrelandets fortid hos nordmanden Snorre såvel som hos danskeren Saxo. For den unge Grundtvig blev følelsen af slægtskab med Norges ånd og fortid en overgang langt stærkere end bevidstheden om dansk herkomst. Selv har han bl.a. udtrykt det således: "Hvadenten jeg nu er oprindelig dansk eller ikke, saa varede det en god Stund, før jeg fandt mig i den danske Handlemaade, som forekom mig søvnagtig og kraftløs. Norges Aand derimod, som den hvilede over "Olaverne», tiltalte mig særdeles. " På denne baggrund må man nok også bedømme hans forkærlighed for Baggesen, i hvis åndelige fysiognomi han mente at kunne spore specielt norske træk. Ligesom han tillagde det betydning, at hans fætter, Henrich Steffens var født i Norge.

Sympati for Norge og nordmændene var Grundtvig ikke ene om at nære i datidens København. Den kan føres helt tilbage til midten af det 18. århundrede, og tog et nyt opsving takket være Oehlenschlägers ungdomsdigtning. Den store norske histo-

Foredrag ved Grundtvig-Selskabets årsmøde på Lysebu ved Oslo 30. April 1984, bearbejdet og udvidet. 
rieskriver J.E. W. Sars skriver, at nordmænd i Danmark, i hine tider, "behandledes ikke bare som jevnbyrdige med danskerne, men mere end det - ofte meget mere end det - Norge og nordmænd spillede i den danske opinion, i Kjøbenhavns klubliv og ledende litterære kredse, en rolle, som måtte tilfredsstille endog en meget fordringsfuld nationalfølelse".

Den unge Grundtvig skilte sig således i dette forhold ikke ud fra mængden af samtidens danskere. Også han sværmede for nordmændene og for hvad han kalder "Norges uforgængelige Storhed ". Når det alligevel er relevant at tage hans forhold til Norge op til særskilt drøftelse, hænger det sammen med, at ikke blot Norges historie, men også Norges fremtid kom til at spille en stor rolle for Grundtvig, ikke blot i hans ungdomsår, men også senere $\mathrm{i}$ hans tilværelse. Jeg har $\mathrm{i}$ dag påtaget mig den opgave at fortælle lidt om, hvordan nogle nordmænd så på Grundtvig omkring årene 1808-1814.

1. maj 1808 vendte Grundtvig tilbage til København efter sit mere end treårige ophold på Egeløkke, en herregård på Langeland, hvor han havde gennemgået en modningsproces, ikke mindst takket være den ulykkelig kærlighed til husfruen. Hans kolde hjerte var blevet åbnet for varme følelser, som fremskyndede hans modtagelighed for vigtige sider af samtidens digtning og tanker. På Egeløkke havde han udformet grundtrækkene til sit første betydelige værk "Nordens Mytologi«. Til dette arbejde havde han fået kraftig inspiration af sin ven, bornholmeren P. N. Skougaard, som han betegner som sin tidligste ungdoms eneste ven. Da Grundtvig kom tilbage til København, var han venneløs. Skougaard havde fået en hård dom af censuren for sin Bornholm-beskrivelse og havde forladt hovedstaden.

Det var under disse omstændigheder en lykke for Grundtvig, at han blev alumne på Walkendorf kollegium, og dermed kom i kammeratligt samvær med en række unge studerende, først og fremmest nordmanden Svend B. Hersleb, der studerede teologi. Årene 1808-10 blev derfor $\mathrm{i}$ en vis forstand lykkelige og frugtbringende år for Grundtvig. Han var ved at finde fodfæste på det danske parnas, ikke blot ved sin "Nordens Mytologi «, men også ved udgivelsen af sit første større digteriske værk, "Optrin af Kæmpelivets Undergang i Nord «, december 1809. Det kom derfor ubelejligt, da forældrene lagde et stort pres på ham for at få 
ham hjem til præstegården $\mathrm{i}$ Udby som sin alderssvækkede fars kapellan. Han satte sig længe imod tanken og tyngede derigennem sin samvittighed. Samtidig plagedes han stadig af sin ulykkelige kærlighed, og da han til og med overanstrengte sig ved sit arbejde, endte det med psykisk sammenbrud i december 1810, et sammenbrud, som tog form af et religiøst gennembrud. Det manifesterede sig i hans overgang til en streng luthersk kristentro, som en tid truede med at standse hans udvikling som verdslig skribent.

Vi har kun få litterære vidnesbyrd om hans lykkelige dage på Walkendorf, bl.a. et studentikost og skæmtsomt digt fra oktober 1808 til Hersleb i dennes egenskab af inspector på kollegiet. Et digt, der bl.a. antyder, at Hersleb ikke havde autoritet nok til at sikre, at kollegiets regler for god opførsel i enhver henseende blev opfyldt. I et par korte år fik Grundtvig lejlighed til at føle sig ung blandt de unge, at opleve kollegielivets goder. Derfor kunne han også i et digt takke "de kære Ungersvende, i hvis Forsamling jeg blev ung igen «. Et lignende værdifuldt vidnesbyrd har vi i et digt, Grundtvig skrev i april 1810, da Hersleb forlod kollegiet. Det vidner om, at Grundtvig på dette tidspunkt ikke havde gjort sig fri af sin ulykkelige kærlighed til Constance Leth, og giver samtidig udtryk for Grundtvigs glæde over det venskab, han har sluttet med nordmænd. Det hedder i tidens højstemte sprog, at "Hjertets Samfund med et Frændehjerte har Ahnelsen om Saligheden født", men digteren tilføjer straks: "Maaske kun elsket af en elsket Kvinde, den Salighed kan vorde os til Del«.

Vi har som nævnt kun få vidnesbyrd om Walkendorfsdagenens trængsler og glæder. Derimod har vi nokså fyldige vidnesbyrd om Grundtvigs forhold til nordmænd i tiden efter sammenbruddet i 1810. Grundtvig opholdt sig sandt nok det meste af tiden i Udby, men han kom nu og da til København og havde kontakt med Hersleb og dennes venner.

Den norsk-danske provst og digter Frederik Schmidt kan vi takke for nogle øjebliksbilleder fra foråret 1811, hvor vi ser Grundtvig i selskab med sine norske venner.

Schmidt var født i Danmark af norske forældre, faderen var norsk bisp, og sønnen kom til Norge som fireårig. Her fik han tidlig præsteembede og provsteembede og vandt sig en ganske god position i norske intellektuelle kredse. Han blev i 1814 med-

4 Grundtvig Studier 1985 
lem af rigsforsamlingen på Eidsvoll og var en sand norsk patriot, fuld af vrede og mistænksomhed over for svenskerne og yderst loyal over for danskerne. Han kunne aldrig finde sig i Norges nye status som unionsland og tog i 1820 til Danmark, hvor han blev præst i Himmelev ved Roskilde. Her døde han i 1840.

Han gjorde nogle rejser i det sydlige Europa, og altid med et længere ophold i København som mellemstation. På rejserne førte han, som det var en ret udbredt skik i datiden, en udførlig dagbog, som er bevaret og i 1966-85 udgivet in extenso $i$ to store bind på ialt ca. 1000 tættrykte sider, samt et tredie bind med udførlige kommentarer. Den indeholder mange værdifulde oplysninger.

Schmidt var en fremragende fortæller og en god iagttager, og for os danske er det af stor interesse, hvad han skriver om tilstanden i København, bl.a. om bombardementet af København i 1807.

Ganske særlig interessante er hans beretninger fra et langt ophold i foråret 1811. Det var her, han traf Grundtvig i norske venners kreds. Forinden havde han ubevidst nærmet sig Grundtvig, da han på opfordring af Knud Lyhne Rahbek i april 1811 skrev et bidrag til "Sandsigeren" om Schillers digt "Die Sänger der Vorwelt", hvori Schiller efterlyser det levende ord og dets virkning blandt menneskene. Det levende ord blev et af Grundtvigs vigtigste problemer, baggrunden for hans folkelige pædagogik. Vi har beviser for, at Grundtvig har læst denne afhandling, eftersom der blandt Grundtvigs papirer ligger udkast til et svar på Schmidts artikel, vel at mærke et svar, der viser, at Grundtvig i april 1811, hvor han endnu var mærket af følgerne af den religiøse krise ved juletid i 1810, ikke troede på det profane levende ords livgivende kraft. Mærkværdigvis er der intet i Schmidts dagbog, der tyder på, at Grundtvig mundtligt har diskuteret afhandlingen og Schillers digt med Schmidt, skønt dagbogen viser, at de har været sammen 3 gange i april 1811. Ved disse lejligheder synes Grundtvig konsekvent at have foretrukket at diskutere åndelige materier med den lærde norske filosof Niels Treschow. Det gjorde imidlertid intet skår i Schmidts beundring for den 12 år yngre danske digter og teolog.

1. april 1811 bragte Schmidt et brev til Treschow, "i hvis Sopha jeg fandt Grundtvig, som jeg nu for første Gang saae. "Han var indviklet $i$ en filosofisk-kristelig samtale med den lærde nord- 
mand, "hvori han bl.a. stillede Treschow det Samvittighedsspørgsmaal: „Om en Philosoph kan troe paa sig selv?" "Schmidt fortsætter: "Den Maade hvorpaa disse 2 gode Mænd fremsatte deres forskjellige Meninger om Mysterier, med hvilke man dog aldrig kommer i det Rene, var meget interessant og human. Treschow søgte at forme dem efter og bringe dem i Harmonie med Fornuftens Ideer, men Grundtvig holdt saa stivt ved Systemet, at han end ikke i Henseende til Trinitetslæren taalte mindste Afvigelse fra den Athanasiske Formel. At Grundtvigs Troe paa Christus som den han, efter hans Overbevisning, selv har erklæret sig at være, som overmenneskeligt Væsen og Verdens Forsoner (han vilde ikke lade sig nøje med Navnet: Forløser) er varm, inderlig og uskrømtet, er umiskjendeligt. Den er hos ham Resultatet af forgjæves Grublen og Stræben for at komme til Maalet ad en anden Vej, og han føler sig lykkelig ved denne Troe». Den anden vej, som Grundtvig har søgt, er rationalismens vej, som han vragede ved sit store trosgennembrud.

Her har vi et autentisk koncentrat af Grundtvigs tanker om sin omvendelse kort efter sammenbruddet i 1811. Men vi får også et billede af Grundtvig, som han ser ud kort efter krisen: "I hans mørke Øje og hans Ansigts levende Træk er der noget sværmerisk, men tillige noget blidt «. Karakteristisk for Grundtvigs holdning er det svar, han gav Schmidt, da denne fortalte ham hovedideen i et skrift, "Geist des Urchristenthums", nemlig at "der griechische Sinn und das orientalische Gefühl " i den er sammensmeltet: "Altsaa atter en Christendom uden Christus".

Den 8. april 1811 var Schmidt igen sammen med Grundtvig hos Treschow. Grundtvig var indbudt, men mødte ikke til tiden. Der blev sendt bud efter ham, men næppe var han kommet ind ad døren, "før han og Treschow atter var inde i Philosophie og Theologie». Der blev også drøftet poesi den aften, hvor bl.a. Grundtvig fremhævede Schiller og især "Die Braut von Messina". Af særlig interesse er, hvad Grundtvig ved den lejlighed har sagt om Oehlenschläger, som efter Grundtvigs mening var "ved Overgangen til et nyt System, da en stor Digter, ... stedse arbejdede slettest ". Det hedder hos Schmidt, at Grundtvig kun kan have hørt den første af Oehlenschlägers forelæsninger, "hvor han lagde Grundstenen for sit æsthetiske System, som Grundtvig fandt lagt for løs og Treschow ikke dybt nok ".

Samtalen kom også ind på de nyeste undervisnings- og opdra$4^{\star}$ 
gelsesteorier, et emne, der skulle blive en væsentlig side af Grundtvigs virke. Han fortalte her om et menneske i København, som var blevet opdraget efter Rousseaus "Emil ", "men ulykkeligvis saaledes, at han var blevet halvgal. Da man deraf tog Anledning til at nedrive Rousseaus Emil, skal en anden have anmærket, at den forbemeldte halvgale Person var blevet opdraget efter den danske Oversættelse af Emil «.

Senere drøftede man problemet frihed og nødvendighed. Treschow og Grundtvig var enige om at friheden skulde ombyttes med indvortes nødvendighed, "ligesom Grundtvig fandt, at det vel ikke var bestemt, men forudset af Gud, hvorlunde denne eller hin maatte blive en Skurk og evig fordømt, thi han forsikrede, at han som god og conseqvent Christen heller ikke kunde give Slip paa evige Straffe".

Senere på aftenen kom Grundtvig $\mathrm{i}$ hed disput med Schmidt om Djævelens eksistens, så hed, at Grundtvig bad Schmidt undskylde, hvis han havde overilet sig, "som dog ej var Tilfældet".

Vi făr også et glimt af den umusikalske Grundtvig: "da jeg gik til Pianofortet", skriver Schmidt, "stak han paa sig, maaske fordi han ikke taaler Musik". Det var imidlertid ikke af hensyn til sine svækkede nerver, Grundtvig forlod stuen. Han var virkelig musikfjendsk. Kun da Constance sang for ham om aftenen på Egeløkke, fandt han lidt behag ved tonekunst.

I dagbogen for 8. april făr vi yderligere oplysninger om Grundtvigs udseende. Schmidt mener, at han ligner Baggesen, men tilføjer, at han upåtvivleligt er "et meget bedre Menneske". "Der er som meldt noget forvirret ved hans Øine, dem han undertiden efter en anstrængende Samtale tillukker, som om han vilde samle sig igien ". Endelig får vi oplysninger om den begyndende salmedigter: "Med vor evangelisk-christelige Psalmebog er han meget utilfreds og anmærkede, som mig synes med Grund, at det er en betydelig Mangel ved den, at den ingen historiske Psalmer har, og at den istedet for levende Exempler, fremsætter tør Moral «.

Det er en ejendommelig og bred skildring af den unge Grundtvig, som Schmidt her meddeler. Vi møder både filosoffen, teologen, den litterære kritiker, folkepædagogen og den vordende salmedigter, men også det store, kriseramte menneske, især i slutningen af dagbogsoptegnelsen, hvor det hedder: "Nogen Deel 
turde vel fejlslagne Forhaabninger, ydmyget Stolthed og den Forfølgelse af nogle af Kjøbenhavns Præster, han har været underkastet, og som just ikke giør disse nogen Ære, saavel som legemlig Svaghed have paa hans nærværende Anskuelser af Christendommen, men at de dog fornemmelig ere grundede i Følelsen af hans egen Trang til beroligende Vished saavelsom i den Overbevisning, at Tidsalderens Elendighed ene kan afhjelpes ved sand Religiøsitet, og at denne ene finder fast Grund i Troen paa Christendommens guddommelige Autoritet, derom overtydes man stedse meer, ved at høre den Begeistring, hvormed han taler om dette sit og Menneskehedens vigtigste Anliggende. Ved nærmere Prøvelse turde han maaske finde, at han ikke noksom har adskildt den ægte Christuslære fra Systemet, og at Læren bliver den samme, om end Læreformen er forskjellig. " Det er i virkeligheden et imponerende fyldigt og præcist billede, Schmidt tegner af Grundtvig i 1811. Man ser spirerne til de vækster, han gennem sit liv skulle frempleje.

Lykkeligvis rummer Schmidts dagbog også en skildring af Grundtvigs samvær med nordmænd i et mere muntert lag, hvor vi aner Grundtvigs sans for humor. Den 16.4 var Schmidt inviteret til en anden nordmand, nemlig professor Georg Sverdrup. Her traf han Treschow med frue og datter, den senere (danske) professor i filosofi Sibbern samt Grundtvig og et par andre unge mennesker, Stemann og Hersleb. Anekdoter og lystige indfald skabte animeret stemning. Selv Grundtvig tog virksomt del i denne samtale "og gav broderligt sin Skærv dertil ". Han gengav nogle ret barske beretninger om Holbergs adfærd over for et par af sine professorkolleger til bedste. Senere på aftenen spiste selskabet norske ryper "med behørig Punch til". Det satte gang i den politiske diskussion, idet Treschow og Sverdrup forsvarede Napoleon, mens Grundtvig og Schmidt "nedrev " ham, det bedste de kunne.

Det er ganske opbyggeligt at se den politisk konservative unge Grundtvig i selskab med den dengang meget frihedselskende Frederik Schmidt. Senere i livet byttede de i nogen grad roller.

Men det er måske nok så belysende for kulturbrydningen mellem dansk og norsk i tiden omkring 1814 at følge den norske digterpræsts syn på sin en halv snes år yngre danske kollegas virksomhed som digter og skribent. 
Formentlig var det på den dansk-norske forfatterinde Christiane Korens anbefaling, at Schmidt kort efter sin ankomst til København 1811 havde købt Grundtvigs lige udkomne digtsamling "Idunna ". Hendes hjem - sorenskrivergården på Hovind - nær Gardemoen - var et samlingssted for det datidige Norges intellektuelle "Danomaner". Selv svor hun i årene 1810 til 13 til "Flammesjælen" Grundtvig, og blandt hendes mange "børn" (hun yndede at kalde sig "Moer Koren") var Frederik Schmidt den, hun havde kærest.

Han var dog knap så begejstret som hun for Grundtvigs lille digtsamling. "Idunna vandrer med tunge nordiske Trin og begynder med Kamp og Blod", hedder det i hans dagbog for $5 / 2$ 1811. Et gunstigere indtryk af den unge danske digter fik han et par uger senere, da han hos Rahbek i Bakkehuset hørte skuespillerinden Jomfru Olsen deklamere "Grundtvigs Dedication af hans Nytaarsnat til sin gamle Fader Jubellæreren «.

Selve den lille bog "Nytaarsnat", som Schmidt læste den følgende dag, fandt han "vel meget aandelig og gudfrygtig indtil en Grad af Pietisterie", men mente dog at kunne konstatere, fejlen "ikke var i Grundtvigs Hjerte, men i hans Hjerne, da Piecen er skrevet med Varme og har enkelte virkelig dejlige og poetiske Steder, "

Nogle uger senere (4. marts) gemmer Schmidt "Adresseavisen ", fordi den "mod Sædvane" indeholder "en dejlig Sang i Anledning af en meget elsket og savnet Frue Smiths Død." Schmidt oplyser, at man "Bryder meget sit Hoved med at udfinde Forfatteren, og at man fristes til at gjætte paa Oehlenschläger eller Grundtvig, dersom den sidste ej var paa Langeland. "

Oplysningen om, at Grundtvig i tiden omkring 1. marts 1811 var på Langeland, må bero på misinformation. Det fremgår af et brev til ham fra Constance Leth, dateret 4. april 1811, hvori hun næsten trygler ham om at komme på besøg på Egeløkke (for at han kunne genvinde sit helbred!). Havde Grundtvig en månedstid tidligere været på Langeland, er det utænkeligt, at han ikke havde besøgt familien på Egeløkke.

Schmidt synes her fejlunderrettet. Formentlig et vidnesbyrd om, hvor lidt han kendte til Grundtvig, inden han traf ham personligt blandt norske venner i København.

Så vidt vides traf Schmidt sidste gang Grundtvig den 10. maj 
1811, da Schmidt var i Vartov kirke for at opleve, hvorledes den gamle biskop Balle praktiserede sit forslag til en ny liturgi. Det hedder hos Schmidt: "Grundtvig kom midt under Prædiken og var en andægtig Tilhører".

Nogen nærmere forbindelse kom der ikke mellem dem. Men Schmidt røber i sin dagbog, at han læste de poesier, som fremkom fra Grundtvigs pen under den norske provsts ophold i København i 1811. Han var ikke nogen ukritisk beundrer af den danske skjald, men bekendtskabet med "Dejlig er den Himmel blaa" (i Rahbeks "Sandsigeren" 13. april 1811) behagede ham. Han fandt julesangen "særdeles skiøn, hjertelig og barnlig " - og gav den til bedste under et besøg hos forfatterinden Juliane Jessen.

Også Grundtvigs første verdslige digt efter den religiøse krise 1810, "Anholtstoget", som Rahbek 11. maj 1811 læste op for Schmidt (et par uger før digtet blev trykt i "Sandsigeren ") interesserede den norske provst og skønånd, selvom Grundtvigs genvakte "synkretisme" forvirrede ham: "der hersker (i digtet) temmelig megen lyrisk Uorden, en besynderlig Blanding af nordisk Mythologie og Christendom ..." Men han tilføjer, at digtet "har adskillige skjønne Steder."

Det syntes Grundtvig ikke selv, da han i 1815 genoptrykte digtet i den store samling "Kvædlinger" og bl.a. karkateriserede det som "et koldt Phantasiespil».

En kølig distance til Grundtvig er mærkbar hos Schmidt - som hos andre nordmænd - i tiden efter Kielerfreden 1814. Af Schmidts dagbog fra Rigsforsamlingen på Eidsvoll ser man, at dagbogsskribenten d. 10. maj 1814 har "giennemløbet Grundtvigs lille Piece til Fædrenelandet om dets Tarv og Fare". Nogen kommentar anfører Schmidt ikke. For Eidsvollmanden var det fædreland, som Grundtvig talte om, blevet en anakronisme, og da Treschow i oktober 1814 - under det overordentlige Storthing - lånte ham et exemplar af "Roskilde-Riim ", måtte han indrømme, at den var "haard at fordøie", et indtryk, som ikke ændrede sig, da han d. 11. november igen forsøgte at læse værket. Moer Korens reaktion på Grundtvigs digt med dets mægtige, men uopfyldte forventninger til Norges fremtid som hjemstedet for Bro- 
derkærlighedens menighed, var mere lidenskabelig. "De trætter og saarer mig, og jeg forstaaer dem ikke altid ", havde hun skrevet i sin dagbog d. 28. august 1814. Et par dage senere havde hun tilføjet, at hun intet havde læst af Grundtvig, der havde »interesseret" hende "saa lidt som hans "Riim Krønike" ". Det store kvad med de fejlslagne profetier tyndede ud blandt hans norske venner, og bedre blev det ikke af, at han i digte og prosa følte sig foranlediget til på Danmarks vegne at mane nordmændene til kristelig ydmyghed og bekæmpe deres hovmod. Situationen afspejler sig i Frederik Schmidts senere dagbogsnotater. Da han som optakt til sin store Italiensrejse tilbragte vinteren 1817-18 i København, traf han ikke Grundtvig, som nu boede fast i hovedstaden, dels fordi de norske venner fra opholdet i 1811 var flyttet til Christiania som lærere ved det nye universitet, dels fordi Schmidt ikke opsøgte ham.

Ved et besøg hos den indflydelsesrige prælat J. P. Mynster d. 19. oktober 1817 fik han at vide, at Mynster var utilfreds med sin fætter, "Grundtvigs puerile Giennemhegling af Melanchton"i Grundtvigs tidsskrift "Danne-Virke", og da Schmidt i "Nyeste Skilderie af Kiøbenhavn" læste "et par Salmer af Grundtvig til Reformationsfesten og Luthers Minde", fremkaldte de ingen lovord om salmisten.

En måneds tid senere stiftede Schmidt ved læsning af et nyt nr. af "Danne-Virke" bekendtskab med Grundtvigs storladne digtning "Paaske-Lilien", og "med Forundring" saa han, "at han $i$ selve Poesien undertiden " brugte "det Pøbelsprog, som han synes at forblande med Kraftsprog ". Og om Grundtvigs vægtige afhandling "Om Sandhed, Storhed og Skiønhed " trykt i tredie bind af "Danne-Virke", tilstår han, at han "kun forstaaer meget lidt. "

Frederik Schmidt var i 1817-18 under påvirkning af kredse, der mildest talt stod Grundtvig fjernt. Det gjaldt ikke mindst digteren Jens Baggesen, som i Grundtvig skulle få sin mest kompetente forsvarer, men som ikke desto mindre $i$ et selskab (22/12 1817) gjorde sig lystig over Grundtvigs indlæg i "Kiøbenhavns Skilderie" om den kommende udgave af Saxo og Snorre. Her fandt Schmidt dog anledning til imødegå Baggesens ondskabsfuldheder, idet han vel "fandt at Indlægget var i Grundtvigs underlige Stiil og Maneer, men dog langt fra saa ravgalt, som Baggesen ville giøre det til«. 
Det er det sidste udsagn om Grundtvig, man finder i den norske provsts omfangsrige dagbøger. Det er unægtelig meget frapperende, at der i Schmidts meget detaillerige dagbog fra hans store Italiensfærd med Grundtvigs ven og protegé, digteren B.S. Ingemann, ikke findes eet eneste ord om Grundtvig. Schmidt har kendt J. L. Heibergs "Julespøg og Nytaarsløjer", der efter hans mening "for en stor Deel " består af "flaue og lumpne Løjer ", og han har ikke kunnet undgå i "Danne-Virke" at se Grundtvigts mere velmente end vellykkede forsøg på at tage unge Heiberg i skole i det lange, snakkesalige Riimbrev til Ingemann. På denne baggrund er det bemærkelsesværdigt, at Schmidts dagbog fra Rom ikke med eet ord nævner det store digt "Kjærminde-Bladet", som Grundtvig i efteråret 1818 sendte til Ingemann. Har Ingemann været for blufærdig til at vise Schmidt dette stærkt personlige digt? Eller er forklaringen den, at Grundtvig har været et ømtåleligt emne, som de to helst undgik at drøfte indbyrdes?

Noget nært forhold mellem Schmidt og Grundtvig lader sig ikke påvise. Han kan ikke indrangeres blandt Grundtvigs norske venner, men som en opmærksom og god iagttager ved de få lejligheder, hvor de i 1811 mødtes i København.

Året 1811 var det år, da Frederik VI., tvunget af de politiske omstændigheder gav loven, om oprettelsen af universitetet $i$ Christiania, Det kgl. Frederiks, som det endnu kaldtes i vort århundredes første fjerdedel. Det åbnedes i 1813, og det gav anledning til, at Grundtvig blev skilt fra sine norske venner, først og fremmest Treschow, Hersleb og Georg Sverdrup, der alle fik ansættelse ved det norske universitet.

Det er forståeligt, at det rykkede svært i Grundtvig efter at følge de bortdragne og eventuelt overtage professoratet i historie, eksistentielt engageret $\mathrm{i}$ historien, som han var. Og vennerne så gerne, at han kom derop.

Rescriptet om universitetets oprettelse er dateret 2. september 1811, og fem dage efter skrev Hersleb til Grundtvig, der nu sad i sit exil i Udby, et brev, hvori han antyder, at han allerede den 4. har været i gang med et brev til sin danske ven om universitetssagens løsning. 
Vi kender intet til Grundtvigs reaktion på Herslebs henvendelse, men har et indirekte vidnesbyrd om Grundtvigs personlige syn på universitetssagen og hans personlige ønsker i denne forbindelse i et lidt yngre brev fra Georg Sverdrup til Sibbern. Sverdrup havde med Hersleb som mellemmand lært Grundtvig at kende og var blevet stærkt fængslet af hans personlighed, hans religiøsitet og ikke mindst hans syn på universalhistorien. Kun på eet punkt synes han ikke at kunne følge Grundtvig, nemlig i dennes tro på "et Forsyn, som regjerer endog den mindste af vore Handlinger ". I brevet til Sibbern, dateret 25.12.1811, hedder det om Grundtvig: "Han vil gjerne til Norge til det nye Universitet, og jeg troer, det vilde for dette være en Vinding at besidde ham ". Den 21.4.1812 kan Sverdrup i et brev oplyse Grundtvig om, at han er "blandt dem, Kommissionen har foreslaaet Kongen til Professor i Historie ... Jeg behøver ikke at sige Dem hvor højligen dette har glædet mig og hvor meget godt jeg haaber deraf".

Men i mellemtiden havde Grundtvig fået betænkeligheder. Han skriver til Sverdrup, at han ikke vil forlade Udby med mindre hans far får tilstået en sådan pension, at han efter menneskelig regning kan leve uden næringssorg. Et andet lige så tungtvejende argument er, at han "maaske aldrig kommer til at leve saa rolig og stille glad som nu i det faderlige Hus og som Præst for enfoldige Kristne". Men han tilføjer, at dersom han indser, at det er Guds vilje, vil han "uden Forsagelse eller Mismod vandre ind paa en anden Bane». Samtidig skriver han til sin norskfødte ven Poul Dons: "Det er, mellem os, meldt mig, at jeg er foreslaaet til Professor i Historie ved Norges Universitet ... Noget i mig higer did, noget holder mig hernede."

Georg Sverdrup blev ved med at fyre op under Grundtvig og skrev til ham, som om det var afgjort, at Grundtvig ville komme til Norge: "Jeg kjender ingen, hvis daglige Omgang jeg hellere ønskede mig, og forandrer jeg Stilling, eller rettere Stad, hvortil jeg endnu ikke rigtig kan bestemme mig, da skjer det fornemmeligen i det Haab, at vi dagligen skal komme til at tale og virke sammen."

Der er ingen tvivl om oprigtigheden i Sverdrups og Herslebs ønsker om at få Grundtvig som professor til Norge. Når han ikke kom derop, var skylden i mange henseender hans egen. Tungt 
vejede det naturligvis, at de danske universitetsautoriteter ikke fandt ham videnskabeligt kvalificeret til et professorat $\mathrm{i}$ historie.

Hans "Verdenskrønike" 1812, som i mange henseender bærer vidne om stor lærdom, var i den grad præget af hans personlige kristendomsopfattelse og en ubændig trang til at dømme både levende og døde, ikke mindst landsmænd i hans egen samtid. Det måtte forarge videnskabsmænd af rationalistisk observans at læse hans domme og profetier, hvoraf den mest iøjnefaldende dannede bogens slutning, nemlig profetien om den verdenshistoriske virkning, oprettelsen af Norges Universitet ville få. Denne ekstatiske forudsigelse havde som baggrund en tanke der var slåt ned i ham i efteråret 1810, da han beskæftigede sig med Kotzebue's historie, nemlig troen på at de syv breve i Åbenbaringen (til menighederne i Efesus, Smyrna, Pergamon, Thyatira, Sardes, Philadelphia og Laodicea) i virkeligheden er forudsigelser om syv store folkemenigheder, stadier i kristenlivets historiske udvikling. Det var en tanke, der sin åbenlyse urimelighed til trods, aldrig forlod Grundtvig, og som så sent som i 1860 fandt poetisk form i det store digt "Christenhedens Syvstjerne". Han var overbevist om, at hver af de syv menigheder ville have en varighed af 300 år, og at den 5. menighed, Sardesmenigheden, var den tyske, som var begyndt med Luther 1517, og som altså nu lakkede mod enden, hvorefter den 6 . menighed, Philadelphiamenigheden, ville komme. Og han var ikke i tvivl om, at denne 6. menighed var den nordiske, og at den ville vokse ud af det norske universitet, det nye Wittenberg. Det må tilføjes, at han selv følte sig udpeget (i 1810) til at blive en forløber for en ny reformator, en ny Johan Huss, før en ny Luther.

Der er ud fra et videnskabeligt synspunkt ingen grund til at bebrejde de danske bedømmere af Grundtvigs kvalifikationer som historiker, at de kom til et negativt resultat. Hans navn blev end ikke næunt $i$ indstillingen til de nye professorater. Kort forinden havde han vakt ny og pinlig opsigt ved sit digt "Kvad til Dannerkongen Frederik VI paa hans Fødselsdag den 28. Januar 1812 «. En del af digtet er en tak til kongen for det norske universitet, hvori han skuer hele 300 år tilbage til en anden fyrstelig Frederik, nemlig Frederik den Vise af Sachsen, der ved oprettelsen af universitetet i Wittenberg skabte Gud et nyt Zions bjerg, stedet hvor Luther plantede sit træ, i hvis ly kraften igen voksede i 
Danmark og Norge. Men nu ser det på ny sort ud. I Danmark er "Aftenen nær" og Norges fjelde "beskinnes kun af sidste Aftenrøde«. Med et spring i tanken anråber Grundtvig på ny sin konge:

Et Hus du rejser på det høje Bjerg

Og gid det vorde maa et Wittenberg.

Altså en slags poetisk fortsættelse af den Norges-apoteose hvormed han havde sluttet "Verdenskrøniken 1812«. Så meget mærkeligere er det, at digtet formes som en række anklager mod Norge og nordmændene, først og fremmest Nicolai Wergeland, hvis iøvrigt i flere henseender saglige prisskrift Mnemosyne, om det norske universitet, indeholder en række nålestik mod Danmark og danskerne. Men ikke nok med det. Grundtvig beskylder nordmændene for at være utaknemmelige mod Danmark og for at lide under et ukristeligt hovmod. Kun tilbagevenden til en tro som er født af ydmyghed og kærlighed kan redde slægten og bekæmpe dens synd og vantro:

Det Fjenden er, som dig og os mon true,

Den eneste, for hvilken Nord bør grue.

De hårde anklager mod nordmændene afficerede selvsagt hans norske venner. Selv den milde Hersleb, der altid var parat til at forsvare Grundtvig og hjælpe ham i stort som i småt, reagerede overfor fødselsdagsdigtets aggressioner. Og der er adskillige tegn på at mange nordmænd blev vrede og forargede over digtet. Det forbedrede ikke hans chancer for at blive hentet til Norge. Det ses bl.a. af Claus Pavels dagbøger. Han var en endnu bedre dagbogsskribent end Schmidt, et journalistisk talent som opsporede nyheder, næsten før de var blevet til.

Fra Pavels har vi oplysninger om, hvorledes den norske digter Jonas Rein så på Grundtvig. Pavels er den første, der har noteret sig, at der i februar 1812 har fundet en korrespondance sted mellem Grundtvig og den ældre norske digter Jonas Rein, og kender også indholdet af et brev fra Rein til Grundtvig, hvori Rein har sagt til Grundtvig, at en større sagtmodighed, end Grundtvig ytrer mod anderledes tænkende, anstod en kristendomslærer, samt at Grundtvig på to fulde sider havde svaret, at sagtmodig- 
hed kunne være ret godt til tid og sted, men i en forvendt tidsalder måtte man tale sandheden højt og eftertrykkeligt.

Fra Pavels ved vi også, at Grundtvigs voldsomme fremfærd mod nordmændene blev kritiseret af Bergensbispen Nordal Brun. Pavels skriver i sin dagbog den 14. april 1812: "Han talte $\mathrm{i}$ Dag om Grundtvig, hvis Orthodoxie han vedbørligen berømte, men fandt som alle, der har læst det, hans Ytringer i Brevet til Kongen utidige og fornærmende. Især stødte det ham, at Norge skulde have Danmark at takke for sin Kristendom og Protestantisme".

Man kan af referatet slutte, at Brun havde sympati, ja beundring for Grundtvigs kristendomsopfattelse, som mange andre nordmænd i tiden, men at hans skarpe angreb på det norske hovmod med rette sårede deres nationale følelse. Politiske virkninger havde det udfordrende kvad til kongen dog først da Grundtvig i 1815 genoptrykte det i digtsamlingen "Kvædlinger ". Det inspirerede Nicolai Wergeland til sit voldsomt danskfjendtlige skrift: "Danmarks politiske Forbrydelser mod Kongeriget Norge", som udkom 1816. Her er ingen sympati for Grundtvig at spore.

For Grundtvigs norske venner var det en sorg, at Grundtvig ikke blev indstillet til professoratet ved det nye universitet. Det ses bl.a. af nogle meget venlige breve fra Hersleb, som anbefalede Grundtvig at søge et dansk præstekald og afvente hvad der eventuelt kunne ske. Det kunne jo være at sagen med tiden ordnede sig således at han alligevel blev professor i Norge.

Det samme store håb nærede en anden ung norsk teolog, Stener Stenersen, der i 1814 blev Herslebs kollega som lektor, fra 1818 professor, i teologi ved det norske universitet. Han traf vist nok ikke Grundtvig i 1811, hvor Stenersen var i København for at tage sin teologiske embedseksamen, men satte sig i 1813 brevligt $i$ forbindelse med Grundtvig, som dog først i september det følgende år sendte ham et svar, der til gengæld blev optakten til en brevveksling, der nu med rette vurderes som en såre værdifuld kilde til belysningen af Grundtvigs daværende kristendomssyn.

Fra Stenersen udgik et nyt initiativ for at få Grundtvig til Norge, idet han i august 1813 foreslog Selskabet for Norges Vel, at det skulle anvende hele sin indflydelse på at få Grundtvig til Norge. 
Oplysninger herom har vi fra Claus Pavels, der i sin dagbog for 27. august 1813 skriver, at Stenersen efterlyser en åndelig genfødelse i Norge. Derfor har det nye universitet en mission, forudsat, at der sidder de rigtige folk på dets lærestole. Landets ungdom kan ifølge Stenersen kun "dannes " af "saadanne, der ... have Evne til at fremstille til andres Beskuelse, hvad der rører sig i deres Indre". Men hvor findes "i disse Tider, hvor alt helder til tvende Sider, en saadan Enhed, Helhed og Renhed i Aanden, at den skulde være i stand til ganske at fatte Videnskabens Sands?"

Stenersen har kun eet svar: Hos Grundtvig. Han "stod engang paa samme Standpunkt som vi, men er fra dette gangen ind i Christendommen og har tilkjæmpet sig sin Troe." "Denne Mand ", skriver Pavels, idet han refererer Stenersens proposition, "kunde da kalde Aand i den halvdøde Slægt, og denne Aand skulde ikke i sin Natur være forgjængelig; den skulde øses af den stedse rindende Kilde, af den Eviges Aabenbarelse i Tiden: Christus. "

Men rationalisten Pavels, der meget vel kunne se, at Grundtvig var en mand, der besad usædvanlige evner, følte sig ikke overbevist om, at Grundtvig besad alle de positive egenskaber, som Stenersen havde opregnet i sin proposition, "eller at ingen Mand i hele Norge" besad "dem i ligesaa høi Grad som" Grundtvig. "Efter saa usikre Data at udbede sig ham som Norges sidste og eneste Redningsmand, turde af mange Grunde være betænkeligt «.

Rygtet om Stenersens aktion nåede hurtigt København. Det fremgår bl.a. af et brev, som professor Borge Thorlacius sendte til sin kollega Laurids Engelstoft d. 13. september 1813, og hvori brevskriveren harcellerer over tanken om Grundtvig som historieprofessor. "Det er ellers sært, at Mænd af saa godt Hoved som Treschow og Sverdrup og saa fornuftige som Hersleb kunne forgude Grundtvig. Skulle saadanne Mænd ej kjende Kjernen fra Skallen?" og videre i samme stil.

Men også Grundtvig har været underrettet om Stenersens initiativ. Han søgte på sin fødselsdag, den 8 . september, audiens hos kongen og sagde frimodigt: "Deres Majestæt har sikkert selv fornummet, det staaer ikke til i Landet, som det burde, og Fædrelandskærlighed er ei tilstæde; jeg venter Meget af den Høiskole D. M. har stiftet i Norge, jeg veed, jeg har mellem Fleere været foreslaaet til Professor i Historien, og det ønskede jeg at blive ... jeg troer der at kunne virke meest." 
Hans store ønske blev ikke opfyldt. Men selv da Grundtvig må være blevet klar over, at han kunne skyde en hvid pind efter professoratet, mistede han ikke troen på, at Gud havde udset ham til at øve en stor gerning i Norge, og da han d. 15 . november $i$ Danske Statstidende så en notits om, at kapellaniet til Aggers var ledigt, skrev han i sin dagbog: "DER!"

Af hans korrespondance med Hersleb fremgår det, at han søgte embedet og regnede med at få det. Han var ikke i tvivl om, at det var Gud, der her greb ind i hans skæbne. Det forklarer de profetiske partier, hvormed han sluttede sin reviderede text til "Roskilde Riim " og hvori han - på grundlag af en topografisk beskrivelse af Christiania - malede et temmelig præcist billede af kirken på Aggers bakke, kirken, hvorfra han - efter Guds vilje - skulle øve sin store gerning, nu da Philadephiamenighedens epoke var inde, kirken, som han i "Roskilde Riim" apostroferer med ordene:

Du betegner det Capel,

Som skal staa paa Dovrefjeld.

Men de skønne drømme brast. Netop i de dage, da »Roskilde Riim " udkom, underskrev Frederik den Sjette Kielerfreden, som bragte det mere end 400-årige rigsfællesskab til ophør og lagde Norges skæbne i den svenske tronfølgers hænder. Det fyldte ham med harme ikke blot mod svenskerne, men også mod både nordmændene, som han beskyldte for hovmod og hans danske landsmænd hvis ligegyldighed, materialisme og mangel på gudstro havde vakt Forsynets vrede.

Forhandlingerne på Eidsvoll gav ham til at begynde med et nyt håb, men det smertede ham, at prins Christian Frederik lod sig vælge til norsk konge og endnu mere, at prinsen og nordmændene opgav at kæmpe mod svenskerne. Han var uden forståelse for den nye politiske situation og kom derved på stor afstand af sine tidligere norske venner. Dog ikke den milde Hersleb, der forstod sin danske vens fortvivlelse og sorger, men som ikke kunne følge det råd, som Grundtvig gav både ham og Stenersen, nemlig at ile op til Bergen og modtage deres præstevielse af den djærve bisp Nordal Brun - for som feltpræster at bekræfte norske modstandsstyrker i deres gudstro.

Skuffet måtte Grundtvig erkende sin afmagt og tabet af fordums venner. Vi har et direkte udsagn herom $i$ en selvbiografisk 
optegnelse fra 1815: "jeg var inddragen til Kbhvn 12. september (1814) i Hast for at tale med Professor Sverdrup, som da var hernede, min hele Opmærksomhed var spændt paa Udfaldet af Norges Sag, jeg var selv rede til at drage did og dele alle Farer, hvis jeg hørde, at blot de ønskede mit Komme, som i Foreningens Dage længtes saare efter min Nærværelse. Andet fornam jeg, da Sverdrup ønskede mig som sin Omgangsven, men syntes reent at have glemt, at ved mig Noget kunde udrettes til Norges Vel."

Udtalelsen kan tage sig ud som et bittert punktum for det kapitel i hans liv, der omhandler Grundtvigs norske ungdomsvenner. Den følgende tid belærte ham om, at han også havde mange fjender i det gamle broderland. I fortalen til Danne-Virke II, dateret 13. maj 1817, konstaterer han, "at man i Norge slet ikke vil have med Dannevirke at giøre", men indrømmer, at han "vel paa en Maade kan have fortjent den umaadelige Haan man i Norge udgyder over mit Navn, hvor selv Falsen slaaer det paa Kagen ved Siden af den Nidings, der bagvaskede Dannemark, fortjent den nemlig ved min alt for tidlige og alt for høirøstede Lovsang over Norges Aand, mit alt for lyse Haab om dens Bedrifter". "... at jeg troede, der var mere af Fædrenes gode Aand end i Dannemark, var en Vildfarelse jeg deelde med de bedste Danske, og som i det Ringeste ikke udsprang af Forgabelse i sit Eget." Men han lagde ikke skjul på, at hans håb til fremtiden gjaldt en genoprettelse af det gamle tvillingerige, og at hans håb ikke ville kunne opfyldes, "dersom Norge ikke lærer at takke Gud for Calmar-Unionen". Hvad Gud havde sammenføjet, burde mennesker ikke adskille. Det var tanken bag de visioner, han havde forkyndt om Norges store fremtid.

Den niding og bagvasker, han udpegede, var naturligvis Nicolai Wergeland, hvis skrift om Danmarks politiske Forbrydelser mod Kongeriget Norge gav anledning til en heftig polemik, hvori Hersleb brød en lanse for Danmark og Grundtvig. Han og Grundtvig mødtes aldrig efter, at Hersleb var flyttet til Norge; men forbindelsen holdt de vedlige pr. brev.

Sit venskab med Hersleb havde Grundtvig givet udtryk for, da han i 1824 gav sin søn nr. 2 navnet Svend Hersleb Grundtvig. Sønnen, der vandt internationalt ry som folkemindeforsker, brugte dog aldrig sit mellemnavn, hvad "den gamle» næppe har 
været tilfreds med. Da ungdomsvennen døde (i 1836) hyldede Grundtvig sin trofaste norske ven, hvis liv havde været fattigt på glæder og barnløst, med et stort digt, der bl.a. rummer følgende strofe:
Derfor tidlig jeg opkaldte, I min Søn, min Ungdomsven, For, hvad Fimbulvintren kvalte, Snart i Vaar at se igien, For mig til de gamle Dage En Svend Hersleb at opdrage, I hvis Barm ej fandtes Svig.

Noget bedre kunne han ikke ønske sin søn, end at han blev en ny Svend Hersleb.

Herslebs nære kollega professor Stener Stenersen, der i 1813 havde kæmpet bravt for at få Grundtvig udnævnt til Norge, opsøgte i juli 1816 sin danske ven og sjælesørger, der viste ham rundt i Sydsjælland. Stenersen har - ligesom Frederik Schmidt leveret materiale til et norsk billede af den "unge" Grundtvig. Han karakteriserer ham med ord som venlig, blid, rolig, alvorlig, uden bitterhed - og gennemglødet af følelser for Gud og Fædreland. Deres bekendtskab havde udviklet sig af den i 1813 påbegyndte korrespondance. Den genoptoges for en stund efter Stenersens Danmarksbesøg; men de mødtes aldrig senere.

Stenersen døde året før Hersleb. Sammen udgjorde de Norges første teologiske fakultet og uddannede gennem mere end 20 år Norges præster. De blev aldrig rigtige "Grundtvigianere" i den forstand, at de fulgte deres danske vens kristendomssyn, som det udviklede sig efter "den mageløse Opdagelse«. Men deres beundring og hengivenhed over for deres danske ven og kollega forblev uændret.

Da Grundtvig i 1851 for første og sidste gang satte sin fod på norsk grund - og blev hyldet som en fyrste - åbnede Stenersens enke sit hus for Grundtvigs sønner, der var med på faderens triumftog. Grundtvigs ældste søn, Johan, forlovede sig med Stenersens datter. Han førte hende 4 år senere til Danmark som sin brud. Deres førstefødte søn fik navnet Stener, og søn nr. 2 blev opkaldt efter sin mormor Vilhelmine. Det var den senere chef for 
66

Statsbiblioteket i Århus, Vilhelm Grundtvig, der levede til 1950. Helt op til midten af vort århundrede har mindet om en af Grundtvigs norske ungdomsvenner sat sig spor i slægten. 